\title{
Urgensi Labelisasi Halal Daging Impor di Indonesia
}

\section{Khoiriyah*,}

Magister Ekonomi Syariah, Institut Agama Islam Negeri

Palangka Raya, Kalimantan Tengah, Indonesia

*Corresponding author: khoiriyahgemini@gmail.com
Article history

Received, 23 April 2021

Revised 1, 05 Juni 2021

Revised 2, 20 Juli 2021

Accepted, 28 July 2021

\begin{abstract}
This article discusses the import of meat which has become a polemic, because the halal label was lost or not included in the Indonesian Minister of Trade Regulation, this research is a form of analysis of how important and urgent the halal label is on imported meat in Indonesia as a Muslim-majority country. This study uses a content analysis method with a qualitative approach. Based on the facts and analysis carried out, the researchers concluded that: The halal label on meat imported to Indonesia is very important, because the majority of Indonesian people are Muslims who rely on halal and haram food for a product when consuming it. Halal labels are not enough to ensure a product is always halal. So, in this case, especially meat products, the meat production process must be considered regularly and the role of the state is needed to periodically check the meat production process so that it can always be ensured that it is halal.
\end{abstract}

Keyword: Halal Label, Imported Meat, Indonesia

\begin{abstract}
Abstrak
Artikel ini membahas terkait dengan impor daging yang menjadi polemik, dikarenakan label halalnya sempat hilang atau tidak dicantumkan pada Permendag RI, penelitian ini sebagai bentuk analisis bagaimana penting dan urgennya label halal pada daging impor di Indonesia sebagai negara yang mayoritas Muslim. Penelitian ini menggunkan metode analisis isi dengan mendekatan kualitatif. Berdasarkan fakta dan analisis yang dilakukan maka penelliti mengambil kesimpulan bahwa: Label halal pada daging yang di impor ke Indonesia sangat penting, karena mayoritas masyarakat Indonesia adalah Muslim yang mensandarkan pangannya pada halal dan haramnya suatu produk ketika akan mengkonsumsi. Label halal belum cukup untuk memastikan suatu produk itu selalu halal. Maka dalam hal ini terutama produk daging, harus diperhatikan secara berkala proses produksi dagingnya dan perlu peran negara untuk memeriksa secara berkala proses produksi daging sehingga selalu bisa dipastikan kehalalannya.
\end{abstract}

Kata kunci: Label Halal, Daging Impor, Indonesia

Cite this article:

Khoiriyah(2021). Urgensi Labelisasi Halal Daging Impor di

Indonesia, Jurnal Al-Qardh, 6(1), 52-66.

http://doi.org/10.23971/jaq.v6i.2817

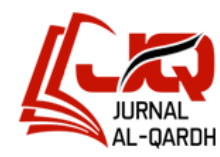

pISSN: $2354-6034$ eISSN: $2599-0187$ 


\section{Pendahuluan}

Penduduk Indonesia yang mayoritas muslim tentunya dalam memilih sesuatu yang akan dikonsumsi pasti mencari yang halal dan thoyyib bagi dirinya. Sehingga ketika ada kabar bahwa label halal yang katanya sempat hilang pada daging impor Indonesia, membuat mereka resah. Hal ini terjadi disebabkan karena pemerintah mengeluarkan Peraturan Mentri Perdagangan (Permendag) Nomor 29 tahun 2019 sebagai pengganti Permendag nomor 59 tahun 2016. Pergantian peraturan itu justru membuat polemik ditengah masyarakat, karena hilang nya label halal pada Permendag yang terbaru, terutama untuk produk daging.

Ketua Asosiasi Perdagangan Daging Indonesia (APDI) Asnawi menilai, pencantuman label halal pada daging impor merupakan hal penting. Bahkan hal ini harus dilakukan negara-negara eksportir daging jika memang mereka ingin memasukkan produknya ke Indonesia. Hal ini menyusul sempat 'hilangnya' ketentuan label halal pada aturan ketentuan impor produk daging. Tidak lagi menempelkan label halal justru menjadi suatu polemik yang sangat dahsyat di masyarakat bahkan menjadi perhatian serius dari semua elemen daripada perwakilan rakyat yang ada di DPR RI. ${ }^{1}$

Aturan Permendag Nomor 29 Tahun 2019 yang tidak mewajibkan pencantuman label halal banyak mendapat penolakan dari anggota DPR. Salah satunya Ketua Fraksi PKS di DPR mendesak, Permendag 29 Tahun 2019 dibatalkan. Karena dia menilai, aturan itu bertentangan dengan UU Nomor 33 Tahun 2014 tentang Jaminan Produk Halal. $^{2}$

Ketentuan wajib label halal pada impor produk hewan sempat menuai polemik karena pada Permendag 29/2019 tentang importasi hewan dan produk hewan, pasal yang mengatur kewajiban label halal tak lagi dicantumkan. Ketentuan halal sejatinya sudah diatur saat proses rekomendasi di Kementerian Pertanian (Kementan). Ketika tidak ada sertifikasi halal, maka Kementan tidak akan memberikan rekomendasi kepada impor. Dengan begitu, ketika rekomendasi tidak diberikan, maka Kemendag pun tidak mengeluarkan izin produk. Ada beberapa poin terkait halal yang harus dipenuhi untuk mendapat rekomendasi. ${ }^{3}$ Namun, untuk menghindari kesalahpahaman, Kemendag akan merevisi Permendag 29/2019 dengan menambah pasal tambahan soal wajib ketentuan dan label halal untuk menegaskan bahwa saat memasukan hewan dan produk hewan (yang diwajibkan halal) ke Indonesia harus wajib halal. Dengan ada tercantumnya label halal dalam kemasan produk makanan menjadi salah satu faktor yang mempengaruhi konsumen untuk membeli.

Berdasarkan polemik yang ada, maka penting bagi kita untuk mengetahui apakah penting label halal itu pada setiap produk yang beredar di Indonesia secara umum dan pada penulisan ini membahas produk daging. Ataukah lebel halal itu tidak penting, yang penting adalah informasi tentang sistem produksi, misal pemotongan hewan ternak nya itu apakah sesuai dengan syariat Islam atau tidak.

1 "Kisruh Label Halal Daging Impor, Apa Kata Pedagang?," accessed April 28, 2021, https://www.cnbcindonesia.com/news/20190919194250-4-100831/kisruh-label-halal-daging-impor-apakata-pedagang.

2 "Mengungkap Alasan Kementerian Perdagangan Menghapus Label Halal Untuk Daging Impor | Merdeka.Com," accessed April 27, 2021, https:/www.merdeka.com/uang/mengungkap-alasankementerian-perdagangan-menghapus-label-halal-untuk-daging-impor.html.

${ }^{3}$ Efrem Siregar, "Wah, Wajib Label Halal di Aturan Daging Impor Sempat 'Hilang,"” news, accessed April 27, 2021, https://www.cnbcindonesia.com/news/20190916122903-4-99707/wah-wajiblabel-halal-di-aturan-daging-impor-sempat-hilang. 


\section{Metode Penelitian}

Penelitian kualitatif dipengaruhi oleh paradigma naturalistik-interpretatif. Dimana peneliti berusaha mengkonstruksi realitas dan memahami maknanya sehingga penelitian ini sangat memperhatikan proses, peristiwa, dan otensitas. Menggunakan metode analisis isi harus mengamati fenomena komunikasi, dengan merumuskan dengan tepat apa yang diteliti dan semua tindakan harus didasarkan pada tujuan tersebut. Selanjutnya memilih unit analisis yang akan dikaji, memilih objek penelitian yang menjadi sasaran analisis. Apabila objek penelitian berhubungan dengan data-data verbal maka perlu disebutkan tempat, tanggal dan alat komunikasi yang bersangkutan. Namun, kalau objek penelitian berhubungan dengan pesan-pesan satu dalam suatu media, perlu dilakukan identifikasi terhadap pesan dan media yang mengantarkan pesan itu. $^{4}$

\section{Hasil dan Diskusi \\ Realita Kebutuhan Konsumsi Daging Impor Indonesia}

Konsumsi adalah mengeluarkan sesuatu dalam rangka memenuhi kebutuhan. Dalam kerangka ekonomi Islam pengeluaran seorang muslim diberdakan menjadi dua tipe. Pertama adalah pengeluaran yang dilakukan seorang muslim untuk memenuhi kebutuhan dunia dan keluarga yang memilki efek pada pahala di akhirat. Kedua adalah pengeluaran yang dilakukan semata -mata untuk mencari akhirat. Penelitian ini dilakukan menggunakan metode deskriftif dengan pendekatan kualitatif. Hasil penelitian ini menunjukan bahwa sasaran kunsumen mencakup tiga aspek 1). Konsumsi untuk dirinya sendiri dan keluarga; Tidak dibenarkan konsumsi yang dilakukan oleh seseorang berakibat pada penyengsaraan diri sendiri dan keluarga karena kekikiranya 2). Tabungan; manusia harus menyiapakan masa depanya, karena masa depanya merupakan masa yang tidak diketahuai keadaanya. Dalam ekonomi penyiapan masa depan dapat dilakukan melalui tabungan 3) Konsumsi sebagai tanggungjawab sosial; konsumsi yang ditujukan sebagai tanggungjawab sosial ialah kewajiban mengeluarkan zakat, hal ini dilakukan untuk menjaga stabilitas dan keseimbangan ekonomi, islam sangat melarang pemupukan harta, yang berakibat terhentinya arus peredaran harta, merintangi efesiensi usaha, dan pertukaran komoditas produksi dalam perekonomian. ${ }^{5}$

Perbedaan konsumsi konvensional dengan konsumsi Islam adalah adanya infak dan lima prinsip konsumsi Islam yaitu keadilan, kesederhanaan, kebersihan, kemurahan hati, dan moralitas. Komponen infak memberi dampak positif bagi diri sendiri yaitu mendapat pahala dan sebagai pengurang zakat yang harus dibayarkan dan memberi dampak jangka pendek yaitu dengan meningkatkan agregat demand. Komponen infak memberi dampak positif bagi orang lain dan dalam jangka panjang meningkatkan kesejahteraan masyarakat pada umumnya melalui penyaluran pembiayaan produktif $A l$ Qardhul Hasan. Teori prilaku konsumen yang Islami dibangun atas dasar syariah Islam. $^{6}$

Salah satu bentuk kebutuhan primer manusia yaitu makanan dan minuman. Ketika manusia tidak makan dan minum dalam jangka dan waktu tertentu akan

\footnotetext{
4 Jumal Ahmad, "Desain Penelitian Analisis Isi (Content Analysis)," ResearchGate. DOI: 10.13140/RG.2.2.12201.08804.

5 Jalaluddin Jalaluddin and Abd Kholik Khoerulloh, "Prinsip Konsumsi dalam Islam: Tinjauan Terhadap Perilaku Konsumen Muslim dan Non-Muslim," Maro: Jurnal Ekonomi syariah dan Bisnis 3, no. 2 (November 14, 2020): 148-60, https://doi.org/10.31949/mr.v3i2.2434.

${ }^{6}$ Imahda Khoiri Furqon, "Teori Konsumsi Dalam Islam," Adzkiya : Jurnal Hukum Dan Ekonomi Syariah 6, no. 1 (May 9, 2018), https://doi.org/10.32332/adzkiya.v6i1.1169.
} 
menyebabkan sakit maupun kematian. Dalam maqasid al-syariyah (tujuan syariat diturunkan) pemenuhan kebutuhan manusia akan makanan dan minuman termasuk dalam kerangka tersebut, seperti hifz al-nafs (menjaga jiwa), hifz al'aql dan hifz al-mal (menjaga harta). Islam sendiri telah memilah-milah makanan dan minuman yang dapat dikonsumsi dan yang mana yang tidak. Dengan standar dan syarat-syarat makanan yang konsumsi harus halal dan baik. ${ }^{7}$

Apapun yang dikonsumsi dalam perspektif Islam memiliki implikasi terhadap kesehatan mental. Oleh karena itu di sinilah diperlukan kesadaran bahwa ketika Allah SWT. telah memberikan rambu-rambu tentang halal dan haramnya suatu makanan atau minuman, maka di situlah ada hikmah di balik ketentuan Allah. Dalam konteks hukum normatif di Indonesia, standarisasi halal juga telah diperkuat dengan Undang-Undang Republik Indonesia Nomor 33 Tahun 2014 tentang Jaminan Produk Halal secara menyeluruh kepada semua lapisan masyarakat. Selain itu Pemerintah juga telah membentuk sebuah badan yang bernama Badan Penyelenggara Jaminan Produk Halal (BPJPH) yang bertugas untuk menyelenggarakan Jaminan Produk Halal (JPH). Hal ini menunjukkan bahwa Pemerintah juga sangat memperhatikan kebutuhan warga negaranya dalam memenuhi konsumsi semua produk dengan standar halal. ${ }^{8}$

Proses penyembelihan yang tidak sesuai syariat Islam mempunyai potensi risiko penurunan kualitas produk dan risiko keharaman karena yang awalnya produk mempunyai status halal akan menjadi haram apabila ada dzat lain yang berstatus haram bercampur dengan dzat yang halal. Manfaat yang akan diambil adalah akan terciptanya loyalitas konsumen akan produk ayam potong yang sudah jelas cara pemotongannya. Oleh karena itu tujuan tulisan ini yaitu untuk mengetahui konsep pemotongan ayam yang sesuai syariat. ${ }^{9}$

Kewajiban pencantuman label dan sertifikat halal sudah diatur dalam Pasal 4 Undang-Undang No 33 Tahun 2014 tentang Jaminan Produk Halal, dan Pasal 2 PP No 31 Tahun 2019 Peraturan Pelaksanaan Undang-Undang No 33 Tahun 2014 tentang Jaminan Produk Halal. ${ }^{10}$

Dalam pemenuhan kebutuhan, Indonesia melakukan melalui impor. Tiga negaraterbesar dalam hal volume impor daging sapidi Indonesia adalah Selandia Baru, USA, dan Australia. Dengan mengetahui permintaanimpor dari ketiga negara tersebut dapatdianalisis seberapa besar pangsa pasarnyadan bagaimana mengontrolnya sehingga dapatdilakukan pengurangan ketergantungan dalam hal impor daging sapi. ${ }^{11}$ Dilansir dari situs arabnews.com pada Senin, 21 Mei 2018, Otoritas Program Halal Pemerintah Australia atau AGAHP selama ini bekerja sama dengan Departemen Pertanian dan sumber daya air serta organisasi-organisasi Islam untuk menciptakan produk-produk halal.Australia bahkan rela mengucurkan investasi jutaan dollar untuk membiayai

${ }^{7}$ Muhammad Hizbullah and Haidir Haidir, "Sosialisasi Pentingnya Mengkonsumsi Makanan Halal Dalam Islam Di PWBI Kwala Bekala," PKM Mаји UDA 1, no. 3 (February 2, 2021): 113-19, https://doi.org/10.46930/pkmmajuuda.v1i3.883.

${ }^{8}$ Muhammad Turhan Yani and Sri Abidah Suryaningsih, "Muslim Consumer Behavior And Halal Product Consumption,” Al-Uqud: Journal of Islamic Economics 3, no. 2 (July 18, 2019): 161-73, https://doi.org/10.26740/al-uqud.v3n2.p161-173.

9 Agus Kholili et al., "Pentingnya Rumah Potong Ayam Halal," LIKUID: Jurnal Ekonomi Industri Halal 1, no. 1 (October 20, 2020), https://journal.uinsgd.ac.id/index.php/likuid/article/view/9993.

10 "Mengungkap Alasan Kementerian Perdagangan Menghapus Label Halal Untuk Daging Impor | Merdeka.Com."

11 Ahmad Syariful Jamil, “Analisis Permintaan Impor Daging Di Indonesia: Pendekatan Error Correction Almost Ideal Demand System," JURNAL PANGAN 27, no. 1 (October 10, 2018): 23-32, https://doi.org/10.33964/jp.v27i1.403. 
penelitian dan pengembangan ilmu pengetahuan bidang daging dan pemahaman bahwa hewan yang sehat, diberi makan dengan baik dan bebas stres adalah prosedur untuk bisa menghasilkan daging berkualitas tinggi yang bisa dinikmati seluruh konsumen.Salah satu persyaratan untuk mendapatkan daging halal adalah hewan harus diperlakukan dengan baik sejak lahir dan diberikan kemudahan akses terhadap makanan, air serta hewan bebas mengaum.Australia dengan lingkungan alamnya dan standar yang tinggi, bisa dengan mudah memenuhi persyaratan ini.Untuk memperketat aturan soal daging halal, seluruh fasilitas di Australia digerakkan oleh perusahaan-perusahaan yang sudah terdaftar di otoritas berwenang dan perusahaan itu melatih para tukang jagal Muslim untuk menjalankan tugasnya. ${ }^{12}$

Undang-Undang No. 33 Tahun 2014 tentang Jaminan Halal bertujuan memberikan kepastian hukum atas status kehalalan produk-produk yang beredar di Indonesia.Undang-Undang ini juga mengubah kewenangan lembaga-lembaga yang terlibat, dimana apabila sebelumnya peran utama dalam proses Sertifikasi Halal berada di tangan MUI dan LPPOM MUI, setelah perubahan dibentuk lembaga baru di bawah Pemerintah untuk menangani permasalahan Jaminan Produk Halal yaitu BPJPH yang memiliki kewenangan mencakup pembentukan regulasi, pemberian Sertifikat Halal dan Label Halal, dan Pengawasan. Namun kewenangan MUI dan LPPOM MUI tidak sertamerta hilang, kedua lembaga tersebut masih memegang peranan penting dalam perlindungan Jaminan Produk Halal. ${ }^{13}$

\section{Urgensi Labelisasi Daging Impor di Indonesia}

Sertifikasi produk halal memiliki implikasi positif dalam membangun iklim bisnis halal di Indonesia.Bagi konsumen sertifikasi halal memberikan perlindungan, jaminan, informasi kehalalan produk dan menjadi instrumen etika bisnis.Bagi para pelaku usaha, sertifikasi halal memberikan keuntungan untuk meningkatkan kepercayaan konsumen dan meraih pasar pangan halal global. Beberapa indikator telah terpenuhi bahwa Indonesia memiliki jumlah penduduk muslim yang sangat besar sekitar 260 juta jiwa atau sekitar $87 \%$ dari total penduduk Indonesia. Jumlah ini akan menjadi pangsa pasaryang menggiurkan. Selain itu, tingkat konsumsi masyarakat indonesia sangat tinggi bahkan tertingi nomor satu di dunia. Maka tidak ada pasar yang paling potensial melebihi Indonesia. Selanjutnya, tinggal bagaimana masyarakat Indonesia mengelolanya. ${ }^{14}$

Fakta bahwa sebagian besar produk makanan halal, terutama daging sekarang bersumber dari berbagai bagian dunia dan mayoritas makanan halal eksportir/produsen berasal dari negara non-Muslim. Hal ini telah menimbulkan keprihatinan yang semakin meningkat dari konsumen makanan halal, terutama masyarakat Muslim. Karena berkaitan dengan apakah status halal dari produk makanan ini benar-benar dapat

12 "Ini Rahasia Australia Jadi Juara Pemasok Daging Halal Di Dunia - Dunia Tempo.Co," accessed April 28, 2021, https://dunia.tempo.co/read/1091176/ini-rahasia-australia-jadi-juara-pemasokdaging-halal-di-dunia.

${ }^{13}$ Iffah Karimah, "Perubahan Kewenangan Lembaga-Lembaga Yang Berwenang Dalam Proses Sertifikasi Halal," Journal of Islamic Law Studies 1, no. 1 (February 6, 2018): 107-31.

${ }^{14}$ Warto Warto and Samsuri Samsuri, "Sertifikasi Halal Dan Implikasinya Bagi Bisnis Produk Halal Di Indonesia," Al Maal: Journal of Islamic Economics and Banking 2, no. 1 (July 14, 2020): 98112, https://doi.org/10.31000/almaal.v2i1.2803. 
dijamin di seluruh rantai pasokan di negara ini dan apakah makanan halal diklaim otentik. ${ }^{15}$

Keprihatinan tentang halal, religiusitas, persepsi kegunaan produk halal dan bahan makanan memiliki dampak yang signifikan terhadap Willingness To Pay (WTP) untuk pangan halal, sementara sikap memiliki dampak yang tidak signifikan pada WTP. Selain itu, tingkat permintaan sertifikasi halal secara signifikan dipengaruhi oleh WTP. ${ }^{16}$ Faktor yang mempengaruhi keputusan umat Muslim yang tinggal di daerah Muslim dan non Muslim ketika membeli produk daging Halal adalah kepuasan pelanggan pada produk yang dibeli dan kinerja logistik halal. Hasil tes menunjukkan bahwa kinerja logistik halal memiliki efek positif dan signifikan pada kepuasan pelanggan. Status halal produk yang didapat dari kinerja logistik halal akan meningkatkan kepuasan dan kesediaan pelanggan untuk membayar. ${ }^{17}$ Jaminan produk halal juga menjadi persyaratan yang wajib dipenuhi ketika negara Indonesia melakukan impor dan ekspor ke negara yang mensyaratkan produk halal.Lembaga yang berwenang mengkaji, menganalisis dan memberikan sertifikasi halal pada produk yang beredar di Indonesia adalah Lembaga Pengkajian Pangan, Obat-obatan, dan Kosmetik Majelis Ulama Indonesia (LPPOM-MUI) ${ }^{18}$

Sertifikasi halal di Indonesia merupakan fatwa yang dikeluarkan oleh Majelis Ulama Indonesia (MUI) secara tertulis untuk membuktikan kehalalan suatu produk yang mana harus sesuai dengan syariah Islam. Sertifikasi halal sendiri digunakan untuk mendapat izin penantuman label halal pada kemasan suatu produk dalam jangka waktu tertentu yang diberikan oleh pihak berwenang. Sertifikasi halal yang dikeluarkan ini tidak terkait dengan Peraturan Menteri Perdagangan (Permendag) Nomor 29 Tahun 2019 tentang Ketentuan Ekspor Impor Hewan dan Produk Hewan. ${ }^{19}$ Hingga saat ini MUI merilis 45 lembaga halal internasional agar memudahkan masyarakat muslim Indonesia ketika bepergian ke Luar Negeri atau ketika Indonesia akan mengimpor, berikut daftar lembaga halal internasional:

Tabel 1.1

Daftar Lembaga Halal Internasional

\begin{tabular}{|c|c|c|c|}
\hline No & $\begin{array}{c}\text { Nama Lembaga Sertifikasi } \\
\text { Halal }\end{array}$ & Alamat dan CP & Status \\
\hline 1 & \begin{tabular}{|lcl} 
Majelis & Ulama & Islam \\
Singapore & (MUIS) & \\
\end{tabular} & $\begin{array}{l}\text { Singapore Islamic Hub, } 273 \text { Braddeli Road, } \\
\text { Singapore } 579702 \mathrm{~T}:+6563591199, \mathrm{~F}:+656253 \\
7572 \text { Email : rahim@ @ muis.gov.sg }\end{array}$ & $\begin{array}{l}\text { Expired } \\
2020 / 06 / 08\end{array}$ \\
\hline 2 & $\begin{array}{l}\text { Jabatan Kemajuan Islam } \\
\text { Malaysia (JAKIM) }\end{array}$ & $\begin{array}{l}\text { Aras 1, Blok D7, Parcel D, Pusat Pentadbiran } \\
\text { Kerajaan Persekutuan W.P. Putrajaya, Kuala } \\
\text { Lumpur, Malaysia T : +603 } 8315 \text { 0200, F : +603 } \\
8889 \text { 4951 Email : hakimah@islam.gov.my }\end{array}$ & $\begin{array}{l}\text { Expired } \\
2020 / 06 / 08\end{array}$ \\
\hline
\end{tabular}

${ }^{15}$ Mohd Hafiz Zulfakar et al., "Halal Accreditation and Certification in A Non-Muslim Country Setting: Insights from Australia Halal Meat Supply Chain," International Journal of Supply Chain Management 8, no. 1 (February 25, 2019): 10-17.

${ }^{16}$ Ahmed, W., Najmi, A., Faizan, H. M., \& Ahmed, S. (2018). Consumer behaviour towards willingness to pay for Halal products. British Food Journal. doi:10.1108/bfj-02-2018-0085.

${ }^{17}$ Zulfakar et al., "Halal Accreditation and Certification in A Non-Muslim Country Setting."

${ }^{18}$ Isti Nuzulul Atiah and Ahmad Fatoni, "Sistem Jaminan Halal: Studi Komparatif Indonesia dan Malaysia," Syi ar Iqtishadi : Journal of Islamic Economics, Finance and Banking 3, no. 2 (November 11, 2019): 37-50, https://doi.org/10.35448/jiec.v3i2.6585.

19 Muhammad Arafat And Anisah Budiwati, "Dampak Penghapusan Kewajiban Label Halal Pada Peraturan Menteri Perdagangan (Permendag) Nomor 29 Tahun 2019 Pada Kebijakan Sertifikat Halal Lppom Mui Yogyakarta,” At-Thullab Jurnal Mahasiswa Studi Islam 2, no. 1 (September 14, 2020): 223-36. 


\begin{tabular}{|c|c|c|c|}
\hline 3 & $\begin{array}{l}\text { Bahagian Kawalan } \\
\text { Makanan Halal Jabatan } \\
\text { Hal Ehwal Syariah }\end{array}$ & $\begin{array}{l}\text { Tingkat II, BangunanKementerian Hal EhwalUgama } \\
\text { (LAMA),Jalan Elizabeth, Bandar Seri Begawan BS } \\
3510 \text { Negara Brunei Darussalam T : +673 2242565, F } \\
:+6732223106\end{array}$ & $\begin{array}{l}\text { Expired } \\
2020 / 06 / 08\end{array}$ \\
\hline 4 & $\begin{array}{l}\text { Muslim Professional } \\
\text { Japan Association } \\
\text { (MPJA }\end{array}$ & $\begin{array}{l}\text { Yoshioka Build 3F, 4-32-1 Yotsuya, Shinjuku-ku, } \\
\text { Tokyo 160-0004, Japan, P : +813 } 68691046 /+813 \\
62748392 \text { Email : akmal@ @malalc.jp }\end{array}$ & $\begin{array}{l}\text { Expired } \\
2021 / 10 / 16\end{array}$ \\
\hline 5 & $\begin{array}{l}\text { The Japan Moslem } \\
\text { Association (JMA) }\end{array}$ & $\begin{array}{l}\text { 3-17-23 Higashigotanda, Shinagawa-ku, Tokyo, 141- } \\
\text { 0022 Japan P : +81 } 362773561 \mathrm{~F}:+81362773597 \\
\text { Email : tayeb41831@gmail.com, CP : Prof. Tayeb } \\
\text { Muto }\end{array}$ & $\begin{array}{l}\text { Expired } \\
2020 / 09 / 28\end{array}$ \\
\hline 6 & $\begin{array}{l}\text { Taiwan Halal Integrity } \\
\text { Development Association } \\
\text { (THIDA) }\end{array}$ & $\begin{array}{l}\text { 3, Lane 25, Xinhai Road, Sec. 1, Taipei City, Taiwan } \\
\text { T : +886-2-2367-5231; F : +8862-2365-2094, Email } \\
\text { : thida.info@gmail.com, CP: Isa Chao }\end{array}$ & $\begin{array}{l}\text { Expired } \\
2020 / 09 / 27\end{array}$ \\
\hline 7 & $\begin{array}{l}\text { Jamiat Ulama Halal } \\
\text { Foundation }\end{array}$ & $\begin{array}{l}\text { Imam BADA Compound, Imam Bada Road, Near } \\
\text { Bhindi Bazar, Mumbai - 400 009 (India), P : +91-22- } \\
\text { 23735373, F : +91-22-23759169 Email : } \\
\text { jamiatulamaemaharashtra@ hotmail.com; } \\
\text { contact@ hallacommitee-jum-org. } \\
\text { Halal.committee-jum.org CP : Gulzar Ahmed Azmi }\end{array}$ & $\begin{array}{l}\text { Expired } \\
2020 / 06 / 08\end{array}$ \\
\hline 8 & $\begin{array}{l}\text { Jamiat Ulama I-Hind Halal } \\
\text { Trust }\end{array}$ & $\begin{array}{l}\text { 1 Bahadur Shah Zafar Marg, New Delhi-110002, } \\
\text { India P : +91-11-23322197 F : +91-11-23316173 } \\
\text { Email : jamiathalaltrust@gmail.com CP : Niaz } \\
\text { Ahmed Farooqui }\end{array}$ & $\begin{array}{l}\text { Expired } \\
2020 / 06 / 08\end{array}$ \\
\hline 9 & $\begin{array}{l}\text { Asia Pacific Halal Council } \\
\text { Co Ltd (APHC) }\end{array}$ & $\begin{array}{l}\text { Flat/Rm B 8/F Chong Ming Building } 72 \text { Cheung Sha } \\
\text { Wan Road KL, Hongkong P : +85258083041 } \\
\text { Email : aphccouncil.hk@gmail.com CP : Uztazah } \\
\text { Jannah Ramli }\end{array}$ & $\begin{array}{l}\text { Expired } \\
2019 / 10 / 02\end{array}$ \\
\hline 10 & $\begin{array}{l}\text { The Central } r \\
\text { Council of } \\
\text { (CICOT) }\end{array}$ & $\begin{array}{l}45 \text { Moo } 3 \text { Klongkao Rd., Klongsib, Nongchok, } \\
\text { Bangkok 10530, Thailand T: +662949 } 4114 \text {, } \\
\text { F : } \quad+662 \quad 949 \quad 5904 \quad \text { email } \\
\text { khathawut loh@hotmail.com Cp : Khatawut Murad }\end{array}$ & $\begin{array}{l}\text { Expired } \\
2020 / 09 / 27\end{array}$ \\
\hline 11 & $\begin{array}{l}\text { Halal Certification } \\
\text { Agency (HCA) }\end{array}$ & $\begin{array}{l}\text { Hai Van Tower, } 129 \text { B Tran Dang Ninh, Cau Giay } \\
\text { district, Ha Noi, Vietnam P :+88462693741 F: } \\
+88462671285 \text {, Email: omar@ } @ \text { halal.vn, } \\
\text { CP : Hj. Mohammed Omar }\end{array}$ & $\begin{array}{l}\text { Expired } \\
2021 / 10 / 16\end{array}$ \\
\hline 12 & $\begin{array}{l}\text { Halal Development } \\
\text { Institute of the } \\
\text { Phillipines (HDIP) }\end{array}$ & $\begin{array}{l}\text { Central Bldg, 4F, } 37 \text { Arayat St. Corner Malabito St. } \\
\text { Cubao, Quezon City. Philippines No.10-Ninoy } \\
\text { Aquino Avenue, San Dionisio, Paranaque City, } \\
\text { Philippines P : +025 } 9944 \text { 244, F : +025 6338754 } \\
\text { Email:hdiphilippines@ gmail.com/hdiphillipines@ @di } \\
\text { phalal.com CP : H. Abdulatif S. Sangcupan }\end{array}$ & $\begin{array}{l}\text { Expired } \\
2021 / 10 / 16\end{array}$ \\
\hline 13 & $\begin{array}{l}\text { Halal Accreditation } \\
\text { Council (Guarantee) } \\
\text { Limited }\end{array}$ & $\begin{array}{l}26 \text {-B Retreat Road, Bambalapitiya, Colombo 04, } \\
\text { Sri Lanka T :+94117425 225, F : +94112588050 } \\
\text { Email: ali@ @ac.lk/fari@ hac.lk } \\
\text { CP : Mr. Ali Fatharally/Mr. M.J.M Fari }\end{array}$ & $\begin{array}{l}\text { Expired } \\
2019 / 05 / 26\end{array}$ \\
\hline 14 & $\begin{array}{l}\text { NPO Japan Halal } \\
\text { Association }\end{array}$ & $\begin{array}{l}\text { Address: Excel Abiko 2F, 3-17-4 Karita, } \\
\text { Sumiyoshiku, Osaka, Japan T : +81 6-4703-5966 } \\
\text { F : +816-4703-5977 Email : info@ jhalal.com } \\
\text { CP :Hind Hitomi Remon }\end{array}$ & $\begin{array}{l}\text { Expired } \\
2021 / 10 / 16\end{array}$ \\
\hline 15 & $\begin{array}{l}\text { The Islamic Coordinating } \\
\text { Council of Victoria } \\
\text { (ICCV) }\end{array}$ & $\begin{array}{l}155 \text { Lygon Street, East Brunswick Victoria } 3057 \\
\text { Australia T : +61 } 393805467 \mathrm{~F}:+61393806143 \\
\text { Email : iccv@ @igpond.com }\end{array}$ & $\begin{array}{l}\text { Expired } \\
2020 / 06 / 08\end{array}$ \\
\hline 16 & $\begin{array}{l}\text { Supreme Islamic Council } \\
\text { of Halal Meat in } \\
\text { Australia Inc. (SICHMA) }\end{array}$ & $\begin{array}{l}\text { Unit No. 1/35/37 Harrow Road, Auburn New South } \\
\text { Wales - Australia 2144 T : +61 } 296437775, \text { F }:+61 \\
296437776 \text { Email : halal@ @ichma.com.au }\end{array}$ & $\begin{array}{l}\text { Expired } \\
2020 / 09 / 27\end{array}$ \\
\hline 17 & $\begin{array}{l}\text { Australian Halal } \\
\text { Development \& }\end{array}$ & $\begin{array}{l}\text { Address } 839 \text { Beaudesert Road, Archerfield 4108, } \\
\text { Brisbane, Qld, Australia P/F +61 } 732751077 \text { / +61 }\end{array}$ & $\begin{array}{l}\text { Expired } \\
2019 / 08 / 31\end{array}$ \\
\hline
\end{tabular}




\begin{tabular}{|c|c|c|c|}
\hline & Accreditation (AHDAA) & $\begin{array}{l}\text { 733738411, CP : Ali Warsama, Email : } \\
\text { info@ahdaa.com.au, Website : www.ahdaa.com.au }\end{array}$ & \\
\hline 18 & $\begin{array}{l}\text { Global halal Trade } \\
\text { Center Pty Ltd (GHTC } \\
\text { Pty.Ltd) }\end{array}$ & $\begin{array}{l}\text { Level 1, } 27 \text { Basswood Street, Algester, QLD 4115, } \\
\text { Australia T : +61 432171255 Email : } \\
\text { info@globalhalaltrade.com CP : Taoufik Elidrissi }\end{array}$ & $\begin{array}{l}\text { Expired } \\
2020 / 08 / 07\end{array}$ \\
\hline 19 & $\begin{array}{l}\text { Western Australian Halal } \\
\text { Authority (WAHA }\end{array}$ & $\begin{array}{l}\text { Unit 2/64 Attfield Street, Maddington, WA 6109, } \\
\text { Australia T : +61 } 894594216 \text { F : +61 } 894598323 \\
\text { Email : info-waha@ @estnet.com.au } \\
\text { Website : www.halalbooklet.com }\end{array}$ & $\begin{array}{l}\text { Expired } \\
2020 / 08 / 08\end{array}$ \\
\hline 20 & $\begin{array}{l}\text { Australian Halal } \\
\text { Authority \& Advisers } \\
\text { (AHAA) }\end{array}$ & $\begin{array}{l}135 \text { Sydney Road, Coburg VIC } 3058 \text { Australia } \\
\text { (Melbourne Office) P : +61 393846939 } \\
\text { Email : ahaaservices@ gmail.com, CP : Azmi Raid } \\
\text { Badres }\end{array}$ & $\begin{array}{l}\text { Expired } \\
2020-09- \\
12\end{array}$ \\
\hline 21 & $\begin{array}{l}\text { Global Australian Halal } \\
\text { Certification (GAHC }\end{array}$ & $\begin{array}{l}\text { Suite 3/20-21 Bankstown City Plaza, Bankstown, } \\
\text { Sidney NSW } 2200 \text { P: +61 421050941, } \\
\text { Email : nsiregar@gahc.com.au }\end{array}$ & $\begin{array}{l}\text { Expired } \\
2021 / 05 / 27\end{array}$ \\
\hline 22 & $\begin{array}{l}\text { Asia Pasific Halal Service } \\
\text { - New Zealand, Pty } 2011 \\
\text { Limited (APHSNZ-Pty } \\
2011 \text { ltd) }\end{array}$ & $\begin{array}{l}\text { Prime Property House, Level 2, } 2 \\
\text { Woodward Street, Wellington } 6142 \text { New } \\
\text { Zealand, PO Box } 11645, \\
\text { Wellington } 6142 \text { New Zealand } \\
\mathrm{T}:+64 \text { 44734675, F : + } 6444734674 \\
\mathrm{CP}: \text { Mr. Mohamud Mohamed } \\
\text { Mobile : + } 64212376571 \\
\text { Email : mohamud.m@ paradise.net.nz }\end{array}$ & $\begin{array}{l}\text { Expired } \\
2020 / 06 / 08\end{array}$ \\
\hline 23 & $\begin{array}{l}\text { New Zealand Islamic } \\
\text { Development Trust } \\
\text { (NZIDT) }\end{array}$ & $\begin{array}{l}\text { Level 4-369 Queen Street, } \\
\text { PO Box 5045, Auckland City, } 1010 \\
\text { New Zealand } \\
\text { P : } 09 \text { 306 8934, F : } 09306 \text { 8935, } \\
\text { Email : halal@ nzidt.co.nz } \\
\text { CP. : Taoufik Elidrissi }\end{array}$ & $\begin{array}{l}\text { Expired } \\
2020 / 09 / 27\end{array}$ \\
\hline 24 & $\begin{array}{l}\text { The Federation of } \\
\text { Islamic Association of } \\
\text { New Zealand, Inc } \\
\text { (FIANZ) }\end{array}$ & $\begin{array}{l}\text { 7-11 Queens Drive, Kilbirnie, Wellington } \\
6022 \text {, New Zealand } \\
\text { T : +64 } 275710929 \\
\text { F : +64 } 43878023 \\
\text { Email: tahir.nawaz@ fianz.co.nz } \\
\text { Website: www.fianz.co.nz } \\
\text { CP : Mr. Tahir Nawaz }\end{array}$ & $\begin{array}{l}\text { Expired } \\
2019 / 10 / 02\end{array}$ \\
\hline 25 & $\begin{array}{l}\text { Halal Food Council of } \\
\text { Europe (HFCE) }\end{array}$ & $\begin{array}{l}\text { Rue de La Presse, 1000, Brussles, } \\
\text { Belgium } \\
\mathrm{T}:+32.2227 .1114, \mathrm{~F}:+32.2218 .3141 \\
\text { Email : drmsadek@hfce.eu } \\
\text { CP: Prof. Dr. Mohamed Sadek }\end{array}$ & $\begin{array}{l}\text { Expired } \\
2020 / 09 / 28\end{array}$ \\
\hline 26 & $\begin{array}{l}\text { The Muslim Religious } \\
\text { Union of Poland (MRU) }\end{array}$ & $\begin{array}{l}\text { 15-207 Bialystok, ul. Piastowska 13F, } \\
\text { Poland or mailing address : } \\
\text { skr.pocz.nr2,ul. Mieszka 114. 15-050 } \\
\text { Bialystok 8, Poland } \\
\text { T / F : +0048856643516 } \\
\text { Email : mzr@ @zr.pl, } \\
\text { project.mzr@gmail.com } \\
\text { Website : www.mzr.pl, } \\
\text { CP: Tomasz Miskiewics (Mufti Poland) }\end{array}$ & $\begin{array}{l}\text { Expired } \\
2020 / 06 / 08\end{array}$ \\
\hline 27 & $\begin{array}{l}\text { Halal Quality Control } \\
\text { (HQC) }\end{array}$ & $\begin{array}{l}\text { Laan van Meerdervoort 53d, } 2517 \\
\text { AE the Hague, The Netherlands } \\
\mathrm{T}:+31703469795, \mathrm{~F}:+31703450033 \\
\text { Email : info@ halaloffice.com, } \\
\text { 22@ } @ \text { hotmail.com, CP: Munim Al Chaman } \\
\text { Pallaswiesenstrasse. 63, } 64293 \\
\text { Darmstadt, Germany } \\
\mathrm{T}:+4961513609850\end{array}$ & $\begin{array}{l}\text { Expired } \\
2020 / 06 / 08\end{array}$ \\
\hline
\end{tabular}


Jurnal Al-Qardh, Vol. 6, No.1, Juli 2021, hlm. 52-66

\begin{tabular}{|c|c|c|c|}
\hline & & $\begin{array}{l}\text { Email: info@ @qc-germany.com, } \\
\text { Web: www.hqc-germany.com } \\
\text { CP: Dr. Abdullah Hito } \\
\text { BramscherStr.67, } 49088 \text { Osnabrueck,-Germany } \\
\text { T:+49 (0)541/94536876 } \\
\text { M :+49(0)1773160482 } \\
\text { E-Mail :info@ halalquality.de } \\
\text { Web: www.halalquality.de } \\
\text { General Manager: Dr. Ibrahim Salama } \\
\text { Halal Quality Control Denmark: } \\
\text { Agro Food Park 13, 8200 Aarhus, } \\
\text { Denmark +45 2830 9606 lillian@ @alaloffice.com | } \\
\text { denmark@ @alaloffice.com } \\
\text { Contact: Mrs. Lillian Dakkak } \\
\text { Halal Quality Control Austria: } \\
\text { Address: Firmenbuchgericht Wien, FN } 469056 \\
\text { Telephone: +43 677 62 } 434549 \\
\text { E-mail: ahmed.sherif@ } 49 \text { c.at } \\
\text { Contact person: Dr. Ahmed Sherif }\end{array}$ & \\
\hline 28 & $\begin{array}{l}\text { Instituto Halal De Junta } \\
\text { Islamica (Halal Institute } \\
\text { of Spain) }\end{array}$ & $\begin{array}{l}\text { Fuente Arriba, s/n } 14720 \\
\text { Almodovar deRio - Cordoba, Spain } \\
\text { T : +34 902431937, } \\
\text { F : +34 957713203 } \\
\text { Email : international@ institutohalal.com } \\
\text { Website: institutohalal.com } \\
\text { CP: Mariam Isabel Romero } \\
\end{array}$ & $\begin{array}{l}\text { Expired } \\
2020 / 09 / 28\end{array}$ \\
\hline 29 & $\begin{array}{l}\text { World Halal Authority } \\
\text { (WHA) }\end{array}$ & $\begin{array}{l}\text { Via Gaetano Salvemini, 09, Italy } \\
\text { Phone: +390236587564 } \\
\text { Fax: +390295441130 } \\
\text { Email: info@ wha-halal.org } \\
\text { CP:Mohamed Elkafrawy }\end{array}$ & $\begin{array}{l}\text { Expired } \\
\text { 2021/10/16 }\end{array}$ \\
\hline 30 & $\begin{array}{l}\text { Total Quality Halal } \\
\text { Correct Certification } \\
\text { (TQHCC) }\end{array}$ & $\begin{array}{l}\text { PO. BOX. 179, } 2300 \text { AD Leiden, } \\
\text { Nederland } \\
\mathrm{T}:+31 \text { 715235770, } \\
\mathrm{F}:+31715235771 \\
\text { Email : info@ halalcorrect.com } \\
\text { Centroallee 273-277, } 46047 \text { Oberhausen, } \\
\text { Germany } \\
\mathrm{T}:+49(0) 208-88027110 \\
\mathrm{~F}:+49 \text { (0)208-8802 } 7001 \\
\text { Email : Germany@ @alalcorrect.com } \\
\mathrm{CP}: \text { Taoufik Maatoug }\end{array}$ & $\begin{array}{l}\text { Expired } \\
\text { 2021/10/16 }\end{array}$ \\
\hline 31 & $\begin{array}{l}\text { Halal Certification } \\
\text { Europe (HCE) }\end{array}$ & $\begin{array}{l}\text { PO. BOX } 1786 \text { Leicester LE5 5ZE, } \\
\text { England, UK/12 Mayfields Wembley HA9 } \\
\text { 9PS, P/F : +44 } 116273 \text { 8228, } \\
\text { Email : halal@ halalCE.com, } \\
\text { yusuf@ halalCE.com } \\
\text { CP : Yusuf Abo Bakar }\end{array}$ & $\begin{array}{l}\text { Expired } \\
2020 / 09 / 27\end{array}$ \\
\hline 32 & $\begin{array}{l}\text { Halal Food Authority } \\
\text { (HFA) - UK }\end{array}$ & $\begin{array}{l}\text { 3rd } \\
\text { Floor, Balfour House } \\
741 \text { High Road } \\
\text { London N12 0BP, UK } \\
\text { Email : info@ halalfoodauthority } \\
\text { Web : www.halalfoodauthority.com } \\
\text { CP : Saqib Mohammad }\end{array}$ & $\begin{array}{l}\text { Expired } \\
2021 / 10 / 16\end{array}$ \\
\hline 33 & $\begin{array}{l}\text { Halal Feed and Food } \\
\text { Inspection Authority } \\
\text { (HFFIA) }\end{array}$ & $\begin{array}{l}\text { Neherkade 3140, } 2521 \text { VX, The Hague, } \\
\text { The Netherlands // PO BOX } 16786 \text { / } 2500 \\
\text { BT / the Hague / The Netherlands } \\
\text { P: +31-703649191, }\end{array}$ & $\begin{array}{l}\text { Expired } \\
\text { 2021/03/28 }\end{array}$ \\
\hline
\end{tabular}




\begin{tabular}{|c|c|c|c|}
\hline & & $\begin{array}{l}\text { F : +31-703645460 } \\
\text { Email: application@ halal.nl, } \\
\text { yasmina@ halal.nl } \\
\text { Website : www.halal.nl } \\
\text { CP : Yasmina Ben Koubia }\end{array}$ & \\
\hline 34 & $\begin{array}{l}\text { Halal Certification } \\
\text { Services (HCS) }\end{array}$ & $\begin{array}{l}\text { Salinenstrasse 18, } 4310 \text { Rheinfelden, } \\
\text { Switzerland } \\
\text { T : + } 41618133064, \\
\text { F }:+41618133065 \\
\text { Email : info@ } \text { swisshalal.ch, } \\
\text { ftufail@ halalcs.org } \\
\text { Website : www.halalcs.org } \\
\text { German Office: } \\
\text { Halal Certification Services (EU)GmbH } \\
\text { Cear-Stünzi-Strasse 1379618 Rheinfelden } \\
\text { (Baden), Germany } \\
\text { T:+ 4930469990384 } \\
\text { Email: info@ halalcs.eu } \\
\text { Website: www.halalcs.eu } \\
\text { CP: Mr. Sheeraz Majeed } \\
\text { Spain Office: } \\
\text { Halal Certification Services S.L. } \\
\text { Calle Poeta Joan Maragall } 60 \text { 2a planta } \\
\text { officina no. 10 Plaza Castilla28020 } \\
\text { Madrid -MADRID, Spain } \\
\text { T: +34 914 528 227 } \\
\text { F: +34 915 714 266 } \\
\text { Email: info@ halalcs.es } \\
\text { CP: Mr. Ali Achcar }\end{array}$ & $\begin{array}{l}\text { Expired } \\
2020 / 09 / 27\end{array}$ \\
\hline 35 & $\begin{array}{l}\text { Eurasia Halal Services } \\
\text { Centre }\end{array}$ & $\begin{array}{l}\text { Karacaoğlan Mahallesi } 6157 / 2 \text { Sokak } \\
\text { No: } 3 / 10, \text { Iş1kkent izmir Türkiye } 35070 \text {, } \\
\text { Turkey } \\
\text { T : +902324610988, } \\
\text { F : +902324610989 } \\
\text { Email : info@eurasiahalal.com } \\
\text { CP : Arzu Gavas }\end{array}$ & $\begin{array}{l}\text { Expired } \\
2019 / 10 / 02\end{array}$ \\
\hline 36 & $\begin{array}{l}\text { HAFSA Halal Certification } \\
\text { and Food Imp\&Exp Ltd }\end{array}$ & $\begin{array}{l}\text { Kizkalesi Sokak Elit Plaza A Blok No: } \\
\text { 1A/24-Serifali / Umraniye,Istanbul / } \\
\text { Turkey } \\
\text { T: +90 } 2123189163 \\
\text { M: +90 5446978104 } \\
\text { Email : info@ @afsahalal.com } \\
\text { Website : www.hafsahalal.com }\end{array}$ & $\begin{array}{l}\text { Expired } \\
2021 / 10 / 16\end{array}$ \\
\hline 37 & $\begin{array}{l}\text { Islamic Foundation of } \\
\text { Ireland (IFI) }\end{array}$ & $\begin{array}{l}\text { 163 South Circular Road, Dublin } 8, \\
\text { Ireland } \\
\text { T : } 0035314533242 \\
\text { F : 003531 } 4532785 \\
\text { Email : ifi@ indigo.ie } \\
\text { CP : Yahya Mohammad Al-Hussein }\end{array}$ & $\begin{array}{l}\text { Expired } \\
2020 / 09 / 11\end{array}$ \\
\hline 38 & $\begin{array}{l}\text { Islamic Services of } \\
\text { America (ISA) }\end{array}$ & $\begin{array}{l}\text { 4334 16th Ave SW P.O Box } 521 \\
\text { Cedar Rapids, Iowa 52404. USA } \\
\text { T : (319) 362-0480, } \\
\text { F : (319) 366-4369 } \\
\text { Email : islamicservices@ @isahalal.org } \\
\text { Website : www.isahalal.org }\end{array}$ & $\begin{array}{l}\text { Expired } \\
2020 / 09 / 27\end{array}$ \\
\hline 39 & $\begin{array}{lll}\text { Halal } & \text { Transaction } & \text { of } \\
\text { Omaha } & & \end{array}$ & $\begin{array}{l}\text { P.O. Box. 4546, Omaha, NE } 68104 \text { USA } \\
\text { T : +1 } 4025726120 \\
\text { F : +1 } 4025724020 \\
\text { Email : hto@ halaltransactions.org }\end{array}$ & $\begin{array}{l}\text { Expired } \\
2020 / 06 / 08\end{array}$ \\
\hline
\end{tabular}




\begin{tabular}{|c|c|c|c|}
\hline 40 & $\begin{array}{l}\text { The Islamic Food and } \\
\text { Nutrition Council of } \\
\text { America (IFANCA) }\end{array}$ & $\begin{array}{l}777 \text { Busse highway - Park Ridge, Illinois } \\
60068 \text { USA } \\
\text { T : 847-993-0034 } \\
\text { F : 847-993-0038 } \\
\text { Email : m.chaudry@ifanca.org } \\
\text { Website :www.ifanca.org } \\
\text { CP: Dr. Muhammad Chaudry }\end{array}$ & $\begin{array}{l}\text { Expired } \\
2020 / 06 / 08\end{array}$ \\
\hline 41 & $\begin{array}{l}\text { Halal Food Council USA } \\
\text { (HFC USA) }\end{array}$ & $\begin{array}{l}\text { 132 E, Main Street, Suite } 302 \text { Salisbury, } \\
\text { MD } 21801 \text { USA. } \\
\mathrm{T}:+14105481728 \\
\mathrm{~F}:+14105482217 \\
\text { Email : hfcinternational@yahoo.com }\end{array}$ & $\begin{array}{l}\text { Expired } \\
2020 / 09 / 27\end{array}$ \\
\hline 42 & $\begin{array}{l}\text { American Halal } \\
\text { Foundation (AHF) }\end{array}$ & $\begin{array}{l}125 \text { N. Vincent Drive Bolingbrook, IL-60490 (USA) } \\
\text { T: +1 6307594981, } \\
\text { F: +16307594981 } \\
\text { Email : mmhussaini@ sbcglobal.net } \\
\text { Cp : Mahzar Hussaini }\end{array}$ & $\begin{array}{l}\text { Expired } \\
2020 / 09 / 27\end{array}$ \\
\hline 43 & $\begin{array}{l}\text { Federation of Muslims } \\
\text { Associations in Brazil } \\
\text { (FAMBRAS) }\end{array}$ & $\begin{array}{l}\text { Rua Tejupa, 188-CEP 04350-020 San } \\
\text { Paula - SP- Brazil. } \\
\text { P : } 005511-5035820 \\
\text { F : 005511-50316586 } \\
\text { CP: Nizar El Ghandour } \\
\text { Email : nizar@ fambras.org.br }\end{array}$ & $\begin{array}{c}\text { Expired } \\
2020-09- \\
12\end{array}$ \\
\hline 44 & $\begin{array}{l}\text { Islamic Dissemination } \\
\text { Centre for Latin America } \\
\text { (CDIAL) Brazil }\end{array}$ & $\begin{array}{l}\text { MarechalDeodoro, Street 1960, Centro Sao Bernardo } \\
\text { do Compo /Sp - Cep 09710 201 - CNPJ } \\
\text { 03.243.138/0001-00., Brazil } \\
\text { T : +114338 8456, F : +114338 } 8456 \\
\text { Email : ali.saifi@cdialhalal.combr }\end{array}$ & $\begin{array}{l}\text { Expired } \\
2020 / 09 / 27\end{array}$ \\
\hline 45 & $\begin{array}{l}\text { National Independent } \\
\text { Halal Trust (NIHT) } \\
\text { South Africa }\end{array}$ & $\begin{array}{l}\text { 5770 Corner Topaas \& Turquoise Street, Extension } \\
\text { 5, Lenasia, } 1827 \text { South Africa, T/F : +27 } 118544382 \\
/+27 \text { 8524300, Website : halal.org.za email : } \\
\text { niht@ halaal.org.za CP : Moulana Abdul } \\
\text { WahabWookay }\end{array}$ & $\begin{array}{l}\text { Expired } \\
2019 / 05 / 26\end{array}$ \\
\hline
\end{tabular}

*) Update Oktober 2019, oleh halalmui.org ${ }^{20}$

Berikut data-data yang disampaikan penulis, yang dikutip dari data MUI yang merilis 45 lembaga halal internasional. Data-data tersebut agar memudahkan masyarakat muslim Indonesia, ketika bepergian ke Luar Negeri atau ketika Indonesia akan mengimpor daging sebagai acuan demi terjaganya kualitas halal daging impor yang masuk ke Indonesia. Data tersebut menjadi acuan dalam membuat keputusan untuk mengimpor daging dari luar negeri yang bisa dipastikan kehalalalannya. Contoh kasus sebaliknya seperti yang terlihat dalam Kasus Impor Daging Ayam, Sertifikasi Halal yang diperdebatkan oleh Brazil akhirnya diputuskan WTO (Word Trade Organization) tetap dapat diberlakukan. Hal ini berarti Indonesia tetap dapat memberlakukan sertifikasi produk tertentu selama itu diterapkan secara sama baik bagi produk yang berasal dari luar negeri maupun dalam negeri. ${ }^{21}$

Pemerintah Indonesia memberlakukankebijakan tersebut bertujuan untuk memenuhi kewajibannya sebagai Negara kepada masyarakatnya untuk menyediakan makanan yang aman, sehat dan halal karena mayoritas masyarakat Indonesia adalah

\footnotetext{
${ }^{20} 9$-Halalmui.org

${ }^{21}$ Marcelino Runtuwarow, "Pemberlakuan Asas National Treatment Dalam Hukum Ekonomi Internasional Dan Implikasinya Bagi Kedaulatan Indonesia (Studi Kasus Impor Daging Ayam Antara Indonesia Dan Brazil Di WTO)," LEX PRIVATUM 8, no. 3 (August 3, 2020), https://ejournal.unsrat.ac.id/index.php/lexprivatum/article/view/29805.
} 
muslim, hal tersebut merupakan bentuk dari hak beragama yang harus dilindungi pelaksanaannya oleh Pemerintah. Brazil menganggap sebagai penyedia rumah potong hewan terbesar maka sudah dapat dipastikan bahwa rumah potong hewannya halal. ${ }^{22}$

Keberadaan daging sapi impor tidak terlalu berpengaruh terhadap harga dan permintaan daging sapi lokal, faktor penyebab kenaikanharga daging sapi lokal masih terletak pada perbedaan jumlah permintaan dan penawaran.Kondisi tersebut disebakan karena terdapat faktor preferensi pada masyarakat danpenyaluran daging impor yang terbatas.Faktor preferensi yang dimaksud adalahterdapatnya perbedaan fisik antara daging impor dan lokal yang menyebabkan dagingimpor kurang diminati. Sedangkan untuk faktor penyaluran daging impor terdapatpembatasan distribusi yang dilakukan oleh BULOG sebagai pihak yang memiliki wewenang untuk melakukan impor daging sapi ke Indonesia. ${ }^{23}$

Selama pembuatan daging segar dan produk daging olahanhalal, sangat penting bahwa semua kemungkinan sumber kontaminasi dihilangkan. Tingkat kebersihan di area produksi dan kebersihan yang dipraktekkan oleh para pekerja tersebut menyumbang untuk inspeksi Toyyiba, oleh karena itu, kualitas dan keamanan makanan dapat dipastikan.Bahaya karena komponen biologis adalah yang paling berbahaya dibandingkan dengan bahaya fisik dan kimia.Penyakit oleh bakteri patogen telahmenjadi masalah kesehatan global, oleh karena itu, sangat penting untuk memiliki inspeksi di titik kontrol yang ditunjuk selama produksi.Poin kontrol halal tidak hanya menekankan pada aspek halal dari produk makanan tetapi juga harus sejalan dengan Hazard Analysis Critical Control Point dari sistem HACCP untuk memastikan bahwa memenuhi toyyiba juga ditegakkan. ${ }^{24}$

Dalam industri daging Halal, sistem ini mencakup dari praktik peternakan yang baik di peternakan sampai manajemen pasca-pemotongan dalam rangka mempertahankan status halal. Aspek kesejahteraan hewan juga disorot dalam mengurangi kemungkinan menyembelih hewan yang terluka atau sakit yang mungkin tidak hanya mempengaruhi kualitas daging tetapi tidak sehat untuk dikonsumsi. Perdarahan yang cepat akibat proses pemotongan akan meningkatkan masa simpan daging dengan mengurangi risiko kontaminasi bangkai dan kerusakan produk. Sebagai konsep toyyiban (wholesomeness) adalah praktek, daging bebas dari bahaya setiap mikrobiologi, fisik dan kimia. ${ }^{25}$

Cara pemotongan dan tahapan pengolahan ayam potong dapat dikelompokan dalam tiga tahapan, yaitu tahapan dalam persiapan ayam, tahapan dalam penyembelihan, dan tahapan dalam pengolahan ayam. Proses penyembelihan yang dilakukan oleh pedagang ayam kelililing, pedagang ayam eceran, dan pemilik bandar ayam yang sekaligus melakukan pemotongan dapat diperinci dalam beberapa tahapan, yaitu; (1). Bagi pedagang ayam kelililing dan pedagang ayam eceran, pengiriman ayam dilakukan dengan menggunakan mobil bak menuju tempat yang dituju. (2). Ayam-ayam

${ }^{22}$ Maudy Fadhilah, “Analisa Yuridis Putusan World Trade Organization Antara Brazil Dengan Indonesia Terkait Kebijakan Impor Daging Ayam Dan Produk Ayam Indonesia," Undergraduate thesis (UNKNOWN, August 2019), http://digilib.ubaya.ac.id/pustaka.php/257754.

23 Thomas Yusar Getaevan, "Penyebab Harga Daging Sapi Lokal Lebih Tinggi Dari Harga Daging Sapi Impor Serta Cara Mengubah Kesenjangan Harga," Calyptra 8, no. 1 (September 1, 2019): 1998-2016.

${ }^{24}$ Bujang, A., Noor, Z. M., \& Abdullah, N. (2018). An Overview of Toyyib Aspect of Halal Food Production in Meat and Meat Products. Proceedings of the 3rd International Halal Conference (INHAC 2016), 467-478. doi:10.1007/978-981-10-7257-4_41.

25 Fazly Ann Zainalabidin et al., "Halal System in Meat Industries," 2019, https://doi.org/10.2478/mjhr-2019-0001. 
yang baru saja didatangkan, kemudian ditempatkan di kandang khusus. (3). Pengambilan ayam dari kandang secara satu persatu oleh penyembelih, dan disembelih dengan membaca basmalah dalam hati. (4). Penyembelihan ayam dilakukan di bagian leher, yaitu di saluran makan, kerongkongan, dan dua pembulu darahnya dengan menggunakan pisau yang tajam. ${ }^{26}$

Kesadaran akan kompleksitas dalam rantai makanan global, dikombinasikan dengan beberapa masalah makanan halal utama dan skandal, merupakan dorongan untuk perubahan besar dalam sistem kontrol makanan halal di Malaysia. Malaysia memegang posisi khusus di pasar halal global sebagai satu-satunya negara yang menugaskan badan pemerintah untuk mengatur masalah dan sertifikasi halal. Sistem kontrol makanan halal di Malaysia yang dibingkai oleh lima komponen penting untuk sistem kontrol pangan nasional yang efektif: peraturan makanan halal; kontrol manajemen makanan halal; pemeriksaan Laboratorium pendidikan, komunikasi, dan pelatihan. Peningkatan yang signifikan telah dibuat pada sistem; Namun, beberapa masalah dan tantangan tetap ada. ${ }^{27}$

Halal dan haram adalah hal yang paling mendasar dalam Islam. Bahkan setiap muslim dalam berbuat wajib memperhatikan halal dan haram nya. Apalagi terkait dengan makanan telah ada perintah Allah SWT, pada Q.S Al-Baqarah, 2:168. Bahwasannya umat Islam tidak boleh memakan daging babi, bangkai, darah, dan hewan yang disembelih menggunakan nama selain Allah SWT. Dengan dasar ini maka, setiap makanan yang diedarkan di kalangan umat Islam haruslah Halal, dalam artian tidak melanggar aturan Allah. Terkait dengan daging, maka harus bukan dari hewan yang dilarang untuk dimakan, dan haruslah disembelih menggunakan nama Allah. Maka, pengimpor daging harus memperhatikan ini ketika akan mengimpor daging ke Indonesia. Apalagi negara-negara pengimpor daging adalah negara-negara yang umat Islam menjadi minoritas disana. Maka perlu ada perhatian penuh dari pemerintah untuk memperhatikan hal ini, dan memeriksa setiap pabrik-pabrik pengimpor daging ke Indonesia, apakah di produksi dengan cara Islam atau tidak. Dan hendaklah pemeriksaan ini tidak hanya dilakukan sekali, tapi secara berkala agar selalu terjamin dan terpercaya kehalalannya.

\section{Kesimpulan}

Label halal pada daging impor Indonesia sangat penting, karena mayoritas masyarakat Indonesia adalah Muslim yang mensandarkan pada halal dan haramnya suatu produk ketika akan mengkonsumsi. Bagi masyarakat non-Muslimpun halal atau haramnya suatu produk makan tidak menjadi masalah bagi mereka, sehingga tidak masalah ketika produk harus berlabel halal. Label halal belum cukup untuk memastikan suatu produk itu selalu halal. Makan dalam hal ini terutama produk daging, maka harus diperhatikan secara berkala proses produksi daging nya. Bisa saja ketika di periksa pertama kali, proses produksinya sesuai dengan syariat sehingga halal. Tetapi tidak bisa pada proses produksi selanjutnya apakah tetap halal atau tidak. Maka perlu peran negara untuk memeriksa secara berkala, tidak hanya selesai ketika telah mendapat label halal.

\section{Daftar pustaka}

26 Afif Muamar and Juju Jumena, "Standarisasi Halal Majelis Ulama Indonesia Dalam Penyembelihan Ayam Di Desa Kertawinangun Cirebon," Al-Ahkam Jurnal Ilmu Syari'ah Dan Hukum 5, no. 1 (September 30, 2020): 89-72, https://doi.org/10.22515/al-ahkam.v5i1.2165.

${ }^{27}$ Ahmad, A. N., Abidin, U. F. U. Z., Othman, M., \& Rahman, R. A. (2018). Overview of the halal food control system in Malaysia. Food Control, 90, 352-363. 10.1016/j.foodcont.2018.02.035. 
Ahmad, A. N., Abidin, U. F. U. Z., Othman, M., \& Rahman, R. A. (2018). Overview of the halal food control system in Malaysia. Food Control,90, 352363.10.1016/j.foodcont.2018.02.035.

Ahmed, W., Najmi, A., Faizan, H. M., \& Ahmed, S. (2018). Consumer behaviour towards willingness to pay for Halal products. British Food Journal. doi:10.1108/bfj-02-2018-0085.

Arafat, Muhammad, and Anisah Budiwati. "Dampak Penghapusan Kewajiban Label Halal Pada Peraturan Menteri Perdagangan (Permendag) Nomor 29 Tahun 2019 Pada Kebijakan Sertifikat Halal Lppom Mui Yogyakarta.” At-Thullab Jurnal Mahasiswa Studi Islam 2, no. 1 (September 14, 2020): 223-36.

Atiah, Isti Nuzulul, and Ahmad Fatoni. "Sistem Jaminan Halal: Studi Komparatif Indonesia dan Malaysia." Syi ar Iqtishadi: Journal of Islamic Economics, Finance and Banking 3, no. 2 (November 11, 2019): 37-50. https://doi.org/10.35448/jiec.v3i2.6585.

Bujang, A., Noor, Z. M., \& Abdullah, N. (2018). An Overview of Toyyib Aspect of Halal Food Production in Meat and Meat Products. Proceedings of the 3rd International Halal Conference (INHAC 2016), 467-478. doi:10.1007/978-98110-7257-4_41

Fadhilah, Maudy. "Analisa Yuridis Putusan World Trade Organization Antara Brazil Dengan Indonesia Terkait Kebijakan Impor Daging Ayam Dan Produk Ayam Indonesia." Undergraduate thesis. UNKNOWN, August 2019. http://digilib.ubaya.ac.id/pustaka.php/257754.

Furqon, Imahda Khoiri. "Teori Konsumsi Dalam Islam.” Adzkiya: Jurnal Hukum Dan Ekonomi Syariah 6, no. 1 (May 9, 2018). https://doi.org/10.32332/adzkiya.v6i1.1169.

Getaevan, Thomas Yusar. "Penyebab Harga Daging Sapi Lokal Lebih Tinggi Dari Harga Daging Sapi Impor Serta Cara Mengubah Kesenjangan Harga." CALYPTRA 8, no. 1 (September 1, 2019): 1998-2016.

Halalmui.org

Hizbullah, Muhammad, and Haidir Haidir. "Sosialisasi Pentingnya Mengkonsumsi Makanan Halal Dalam Islam Di PWBI Kwala Bekala.” PKM Maju UDA 1, no. 3 (February 2, 2021): 113-19. https://doi.org/10.46930/pkmmajuuda.v1i3.883.

"Ini Rahasia Australia Jadi Juara Pemasok Daging Halal Di Dunia - Dunia Tempo.Co." Accessed April 28, 2021. https://dunia.tempo.co/read/1091176/ini-rahasiaaustralia-jadi-juara-pemasok-daging-halal-di-dunia.

Jalaluddin, Jalaluddin, and Abd Kholik Khoerulloh. "Prinsip Konsumsi dalam Islam: Tinjauan Terhadap Perilaku Konsumen Muslim dan Non-Muslim." Maro: Jurnal Ekonomi syariah dan Bisnis 3, no. 2 (November 14, 2020): 148-60. https://doi.org/10.31949/mr.v3i2.2434.

Jamil, Ahmad Syariful. "Analisis Permintaan Impor Daging di Indonesia: Pendekatan Error Correction Almost Ideal Demand System.” JURNAL PANGAN 27, no. 1 (October 10, 2018): 23-32. https://doi.org/10.33964/jp.v27i1.403.

Lubis, Nurul Izzah. (2019), Analisis Loyalitas Konsumen Produk Berlabel Halal, Jurnal Al-Qardh, Vol. 4, No. 1, pp. 51-59, doi: https://doi.org/10.23971/jaq.v4i1.1661

Karimah, Iffah. "Perubahan Kewenangan Lembaga-Lembaga Yang Berwenang Dalam Proses Sertifikasi Halal." Journal of Islamic Law Studies 1, no. 1 (February 6, 2018): 107-31. 
Kholili, Agus, Dadang Ibnu, Evie Indriani, and Nur Solihat. "Pentingnya Rumah Potong Ayam Halal." LIKUID: Jurnal Ekonomi Industri Halal 1, no. 1 (October 20, 2020). https://journal.uinsgd.ac.id/index.php/likuid/article/view/9993.

“Kisruh Label Halal Daging Impor, Apa Kata Pedagang?” Accessed April 28, 2021. https://www.cnbcindonesia.com/news/20190919194250-4-100831/kisruh-labelhalal-daging-impor-apa-kata-pedagang.

"Mengungkap Alasan Kementerian Perdagangan Menghapus Label Halal Untuk Daging Impor | Merdeka.Com.” Accessed April 27, 2021. https://www.merdeka.com/uang/mengungkap-alasan-kementerian-perdaganganmenghapus-label-halal-untuk-daging-impor.html.

Muamar, Afif, and Juju Jumena. "Standarisasi Halal Majelis Ulama Indonesia Dalam Penyembelihan Ayam Di Desa Kertawinangun Cirebon." Al-Ahkam Jurnal Ilmu Syari'ah Dan Hukum 5, no. 1 (September 30, 2020): 89-72. https://doi.org/10.22515/al-ahkam.v5i1.2165.

Pelu, I. E. A., Kurniawan, R., \& Akbar, W. (2020). Developing Sharia Tourism in Fostering Regional Economic Growth (Study on Sharia Tourism at West Nusa Tenggara). Heritage of Nusantara: International Journal of Religious Literature and Heritage, 9(1), pp. 115-142. https://doi.org/10.31291/hn.v9i1.562

Runtuwarow, Marcelino. "Pemberlakuan Asas National Treatment Dalam Hukum Ekonomi Internasional Dan Implikasinya Bagi Kedaulatan Indonesia (Studi Kasus Impor Daging Ayam Antara Indonesia Dan Brazil Di WTO)." LEX PRIVATUM 8, no. 3 (August 3, 2020). https://ejournal.unsrat.ac.id/index.php/lexprivatum/article/view/29805.

Rahmaniar., Farid, F.M., dan Herliani, Yeni. (2017), Pengaruh Perilaku Konsumen dan Label Halal Produk Makanan Rumah Tangga terhadap Keputusan Konsumsi di Palangka Raya, Jurnal Al-Qardh, Vol. 2, No.1, pp. 60-65, doi: https://doi.org/10.23971/jaq.v2i1.827

Siregar, Efrem. "Wah, Wajib Label Halal di Aturan Daging Impor Sempat 'Hilang."” news. Accessed April 27, 2021. https://www.cnbcindonesia.com/news/20190916122903-4-99707/wah-wajiblabel-halal-di-aturan-daging-impor-sempat-hilang.

Warto, Warto, and Samsuri Samsuri. "Sertifikasi Halal Dan Implikasinya Bagi Bisnis Produk Halal di Indonesia." Al Maal: Journal of Islamic Economics and Banking 2, no. 1 (July 14, 2020): 98-112. https://doi.org/10.31000/almaal.v2i1.2803.

Yani, Muhammad Turhan, and Sri Abidah Suryaningsih. "Muslim Consumer Behavior and Halal Product Consumption." Al-Uqud: Journal of Islamic Economics 3, no. 2 (July 18, 2019): 161-73. https://doi.org/10.26740/al-uqud.v3n2.p161-173.

Zainalabidin, Fazly Ann, F. Hassan, Nur Sapinah Mat Zin, W. Azmi, and M. I. Ismail. "Halal System in Meat Industries," 2019. https://doi.org/10.2478/mjhr-20190001.

Zulfakar, Mohd Hafiz, Caroline Chan, Ferry Jie, and Veera Pandiyan Kaliani Sundram. "Halal Accreditation and Certification in A Non-Muslim Country Setting: Insights from Australia Halal Meat Supply Chain." International Journal of Supply Chain Management 8, no. 1 (February 25, 2019): 10-17. 